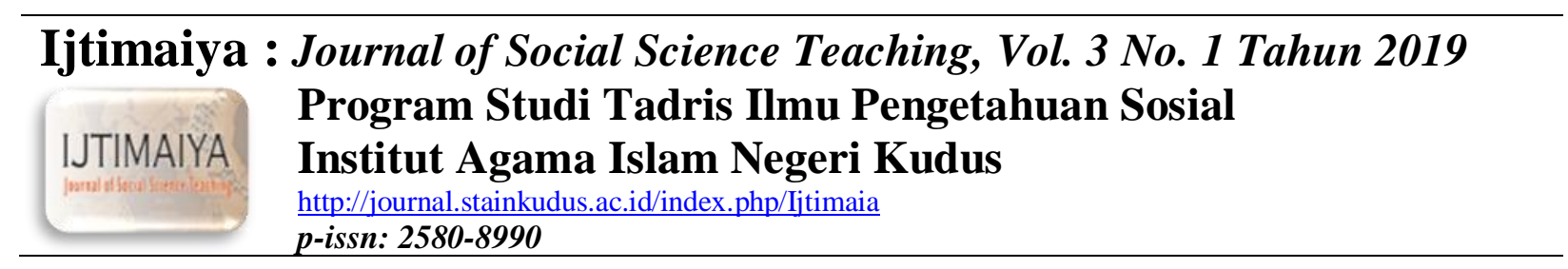

\title{
Penerapan Model Kooperatif TGT Untuk Meningkatkan Keterampilan Sosial dan Hasil Belajar IPS Kelas VIII E SMPN 1 Randudongkal
}

\author{
Hafidz Ady Putra, S.Pd ${ }^{1}$ \\ aSMPN 1 Randudongkal Pemalang, ady_hafidz92@gmail.com
}

\begin{tabular}{|c|c|}
\hline $\begin{array}{l}\text { Informasi } \\
\text { artikel }\end{array}$ & ABSTRACT \\
\hline $\begin{array}{l}\text { Sejarah artikel: } \\
\text { April } 2019 \\
\text { Mei } 2019 \\
\text { Juni } 2019 \\
\text { Keyword: } \\
\text { Social Skills; } \\
\text { Learning } \\
\text { outcomes; } \\
\text { TGT cooperative } \\
\text { model; } \\
\text { Variations of the } \\
\text { game }\end{array}$ & $\begin{array}{l}\text { This research aims: (1) to improve social skill and learning outcomes of social studies of the } \\
\text { eighth graders exactly Class E of SMPN } 1 \text { Randudongkal using TGT cooperative learning } \\
\text { model with variations of the game. This research is Classroom Action Research that uses } \\
\text { the model of Kemmis and Taggart. The Techniques of Collecting data used observation, } \\
\text { interviews, test, field notes and documentation. The result of the research indicated an } \\
\text { improvement of social skills and learning outcomes in social studies after the writer applied } \\
\text { cooperative learning model TGT with variations of the game. The writer can proved there is } \\
\text { the improvement of social skills. Before the action was done, the average of social skills } \\
\text { was } 46.88 \text {, after Cycle } 1 \text {, there was the improvement in } 72.66 \text {, in the end of Cycle } 2 \text {, the } \\
\text { average of social skills became } 80.78 \text {. The improvement of the students' learning outcomes } \\
\text { can also be proved by the classical completeness percentage. The classical completeness } \\
\text { percentage was } 40.62 \% \text { before the action. It was be } 78.12 \% \text { in the end of Cycle } 1 \text { and in the } \\
\text { end of Cycle } 2 \text { improved to become } 87.50 \% \text {. }\end{array}$ \\
\hline
\end{tabular}

\begin{tabular}{ll}
\hline & ABSTRAK \\
\hline Keyword: & Penelitian ini bertujuan untuk meningkatkan keterampilan sosial dan hasil belajar IPS \\
Keterampilan & peserta didik kelas VIII E SMPN 1 Randudongkal melalui model pembelajaran kooperatif \\
Sosial; & TGT dengan variasi permainan. Penelitian ini merupakan penelitian tindakan kelas \\
Hasil Belajar; & (classroom action research) menggunakan desain Kemmis \& Taggart. Teknik pengumpulan \\
Model kooperatif & data dilakukan dengan menggunakan observasi, wawancara, tes, catatan lapangan dan \\
TGT; & dokumentasi. Hasil penelitian menunjukkan terdapat peningkatan terhadap keterampilan \\
Variasi & sosial dan hasil belajar IPS setelah diterapkan model kooperatif TGT dengan variasi \\
permainan. & permainan. Peningkatan keterampilan sosial dapat dibuktikan bahwa sebelum tindakan rata- \\
& rata keterampilan sosial 46,88, setelah akhir Siklus 1 rata-rata keterampilan sosial peserta \\
& didik meningkat menjadi 72,66, setelah akhir Siklus 2 meningkat lagi menjadi menjadi \\
& 80,78. Peningkatan hasil belajar peserta didik dapat dibuktikan dari prosentase ketuntasan \\
& klasikal dari kondisi awal hanya 40,62\%, menjadi 78,12\% di akhir siklus I dan akhir siklus \\
& II meningkat lagi menjadi 87,5\%.
\end{tabular}

Copyright (C) 2019 Tadris IPS Institut Agama Islam Negeri Kudus. All Right Reserved 


\section{Pendahuluan}

Sumber daya manusia yang berkualitas sangat dibutuhkan guna menghadapi tantangan dalam perkembangan ilmu pengetahuan dan teknologi yang semakin maju dan canggih. Penyediaan sumber daya manusia yang berkualitas dan dapat bersaing dalam era globalisasi tidak bisa dilepaskan dari dunia pendidikan dan diyakini bahwa pendidikan menjadi kunci dari keberhasilan di masa mendatang. Oleh karena itu, pendidikan begitu penting dan berpengaruh dalam menen-tukan keberhasilan perkembangan hidup peserta didik. Pendidikan menjadi penentu dalam mem-bentuk manusia Indonesia yang berkualitas. Pendidikan harus benar-benar mampu membentuk manusia Indonesia yang mempunyai kecerdasan mental dan spiritual sehingga terbangun karakter kemanusiaan yang terampil dalam kehidupan bermasyarakat. Seperti pernyataan ini “ humanisasi pendidikan untuk mewujudkan pendidikan yang manusiawi merupakan suatu upaya menjadikan pendidikan sebagai proses pembudayaan. Oleh karena itu tujuan pendidikan tiada lain adalah mengembangkan jasmani, mensucikan rohani dan menumbuhkan akal..." (Zamroni, 2002: 186) Sehingga keberhasilan suatu pendidikan tidak hanya diukur dari pencapaian aspek pengetahuan saja, tetapi yang lebih penting adalah dari aspek sikap dan perilaku.

IPS sebagai salah satu mata pelajaran pada pendidikan dasar, diharapkan mampu memper-siapkan, membina dan membentuk kemampuan peserta didik yang menguasai sikap nilai dan ketrampilan sosial yang diperlukan bagi kehidu-pan di masyarakat. Seperti yang dinyatakan oleh Jarolimek (1986:4) bahwa :

The major mission of social studies education is to help children learn about the social world in which they live and how it got that way; to lern to cope with social realities; and to develop the knowledge. attitudes, and skills needed to help shape an enlightened humanity.
Sehingga dengan mempelajari IPS peserta didik dapat berpartisipasi di lingkungannya untuk dapat memecahkan masalah-masalah pribadi maupun masalah-masalah sosial atau kemasyarakatan. Demi tercapainya tujuan terse-but di atas maka seorang guru IPS dalam proses pembelajaran seharusnya dapat membantu peserta didik untuk meningkatkan keterampilan sosialnya dan sekaligus juga pada peningkatan hasil belajarnya. Peningkatan keterampilan sosial peserta didik bisa dilakukan dengan melatih dan mengajarkan nya dalam proses pembelajaran. Adapun keterampilan yang dapat dilatih dan dia-jarkan dalam pembelajaran menurut William dan Asher antara lain: cooperation, participation, communication, validation (Muijs \& Reynolds, 2006: 171). Oleh karena itu, sebagai pemegang peran yang sangat penting dalam proses pemb-elajaran, guru IPS harus berusaha semaksimal mungkin untuk bisa memberikan materi dengan metode yang tepat, menyenangkan dan menarik dalam pembelajaran sehingga dapat membantu peserta didik meningkatkan keterampilan sosial dan hasil belajarnya.

Proses pembelajaran IPS di SMPN 1 Randudongkal selama ini, guru masih menggunakan metode pembelajaran yang konvensional. Ketika pembelajaran berlangsung, peserta didik hanya duduk diam mendengarkan guru ceramah dan kurang melibatkan peserta didik secara aktif sehingga membuat proses pembelajaran men-jadi sangat membosankan. Kondisi semacam ini diduga dapat berpengaruh terhadap hasil bela-jar IPS peserta didik yang rendah. Hasil belajar IPS yang masih rendah ditunjukkan dari data nilai ulangan harian sebelumnya yang peneliti peroleh, dimana dari 32 peserta didik hanya 13 atau $40,62 \%$ peserta didik yang sudah mencapai KKM, sedang 19 peserta didik atau $59,38 \%$ belum mencapai KKM. Persentase ketuntasan klasikal yang diperoleh kelas VIII E tersebut masih jauh dari standar ketuntasan klasikal yang ditetapkan dalam KTSP SMPN 1 
Randudongkal yaitu 85\%. Selain itu dari hasil observasi yang selama ini peneliti lakukan menunjukkan bahwa ketika mengikuti materi pelajaran IPS peserta didik tampak santai dan kurang memperhati-kan penjelasan guru dan juga sering terdapat beberapa peserta didik yang berbicara sendiri. Ketika guru menggunakan metode ceramah para peserta didik cenderung pasif dalam mengikuti kegiatan pembelajaran. Demikian juga ketika diskusi kelas berlangsung sebagian kecil peserta didik saja yang menyelesaikan kerja kelompok dan biasanya peserta didik yang aktif, sedang sebagian besar yang lain hanya duduk diam menunggu. Di sini terlihat tidak adanya keinginan bekerja sama dan antusias menyelesaikan tugas serta tidak adanya keinginan untuk berkompetisi dalam menyelesaikan tugas di antara peserta didik. Selanjutnya ketika presentasi berlangsung sulit sekali ditemukan peserta didik yang ter-ampil dalam berkomunikasi, peserta didik saling dorong dan saling tunjuk antar peserta didik seh-ingga praktis setiap tahapan pembelajaran diam-bil alih dan didominasi oleh guru. Berdasarkan wawancara yang dilakukan dengan guru-guru pengampu IPS, selama ini guru SMPN 1 Randudongkal kurang berminat untuk mengimplementasikan model pembelajaran secara bervariatif dikarenakan orientasi guru adalah menyelesaikan materi pelajaran bukan orientasi pada kompe-tensi peserta didik dalam pembelajaran, sehingga dalam proses pembelajaran kurang memperhatikan aspek-aspek keterampilan hidup antara lain kerja sama, saling menghargai pendapat, rasa saling memiliki dan lain-lain yang saat ini terasa masih terabaikan.

Berdasarkan temuan tersebut, permasalahan utama dalam pembelajaran IPS adalah bagaimana pengelolaan pembelajaran itu berlangsung sehingga bisa meningkatkan keaktifan, menumbuhkan kreativitas peserta didik dalam belajar dan peserta didik termotivasi untuk belajar. Pengelolaan pembelajaran dengan menggunakan metode dan model yang tepat akan meningkatkan keterampilan sosial peserta didik dan akan berdampak pula pada meningkatnya hasil belajar. Salah satu model pembelajaran yang dapat digunakan dalam upaya meningkatkan keterampilan sosial dan hasil belajar IPS adalah dengan menggunakan model kooperatif tipe TGT (teams games tournament) yang permainannya divariasi.

Teams Games Tournament (TGT) merupakan salah satu jenis atau tipe dari model pembelajaran Cooperative Learning atau pembelajaran kooperatif. Pembelajaran ini mengutamakan kegiatan dengan melibatkan interaksi antar peserta didik dalam kelompokkelompok belajar.

Interaksi peserta didik dalam kelompokkelompok belajar dikemukakan Slavin (1995: 5) yang menjelaskan tiga konsep penting dalam pembelajaran kelompok yaitu penghargaan bagi tim, tanggung jawab individu dan kesempatan sukses yang sama. Penghargaan tim diberikan kepada tim yang berprestasi, sehingga perlu kerja sama yang baik antar anggota kelom-pok. Semua peserta didik memberikan kontribusi terhadap kesuksesan kelompoknya dengan tidak memandang peserta didik berprestasi tinggi, sedang ataukah rendah. Peserta didik didorong untuk saling membantu dalam mempelajari bahan yang bersifat akademik atau dalam melakukan tugas kelompok karena kesuksesan kelompok tergantung pembelajaran individu dari semua anggota kelompok.

Model kooperatif TGT mempunyai keung-gulan tersendiri. Salah satu keunggulan dalam TGT adalah menggunakan permainan yang dapat disesuaikan dengan topik apapun (Slavin, 1991: 342). Selain itu, TGT juga mengguna-kan turnamen yang dapat membuat peserta didik lebih bersemangat dan termotivasi dalam proses pembelajaran.

Pembelajaran dengan model kooperatif TGT menuntut peserta didik bekerja dalam tim untuk menyelesaikan tugas-tugas yang diberikan oleh guru dan sekaligus untuk mempersiapkan anggota timnya guna mengikuti game akademik yang 
diturnamenkan pada akhir kompetensi dasar selesai. Dengan demikian pembelajaran IPS melalui model kooperatif TGT dengan variasi permainan akan menjadikan peserta didik termotivasi untuk meningkatkan kerja sama dan komunikasi di timnya demi mempersiapkan anggota timnya untuk memperoleh kemenangan dalam turnamen. Sehingga pembelajaran dengan model kooperatif TGT akan lebih menantang, menarik dan menyenangkan. Adanya peningkatan kerja sama dan komunikasi dalam tim akan berimplikasi juga terhadap peningkatan hasil belajar peserta didik. Oleh karena itu model kooperatif TGT yang diintegrasikan dalam pembelajaran IPS diharapkan bisa menjadi solusi untuk masalah tersebut, sehingga dapat mewujud-kan apa yang menjadi tujuan pembelajaran IPS yaitu mempersiapkan, membina dan membentuk kemampuan peserta didik yang menguasai sikap, nilai dan keterampilan sosial yang diperlukan bagi kehidupan di masyarakat.

Berdasarkan penelitian yang dilakukan oleh A.A.G. Ngurah (2005:148-162), Sri Widarwati (2007: 224-239), Puji Rahayu (2011: 57-64), dan Suranto (2011: 79-90) dapat ditarik kesimpulan bahwa penerapan model pembelajaraan kooperatif TGT dapat meningkatkan aktivitas, keterampilan kooperatif, kreativitas, menumbuhkan kemauan untuk berkreasi dan hasil belajar peserta didik. Untuk itu berdasarkan hasil kajian tersebut maka peneliti bermaksud melakukan penelitian tindakan kelas untuk mengetahui bagaimana pembelajaran kooperatif TGT dengan variasi permainan dapat mening-katkan keterampilan sosial dan hasil belajar IPS peserta didik di SMPN 1 Randudongkal Magelang.

\section{Metode}

Penelitian ini menggunakan desain peneli-tian tindakan kelas model Kemmis \& Taggart. Penelitian tindakan kelas model ini dikem-bangkan melalui reflektif spiral yang dimulai dari rencana, tindakan (implementasi tindakan), observasi, refleksi, kemudian perencanaan kem-bali, implementasi lanjut, observasi dan refleksi (Kemmis \& Taggart, 1990: 22). Adapun prosedur penelitian diilustrasikan dalam bentuk siklus sebagai berikut:

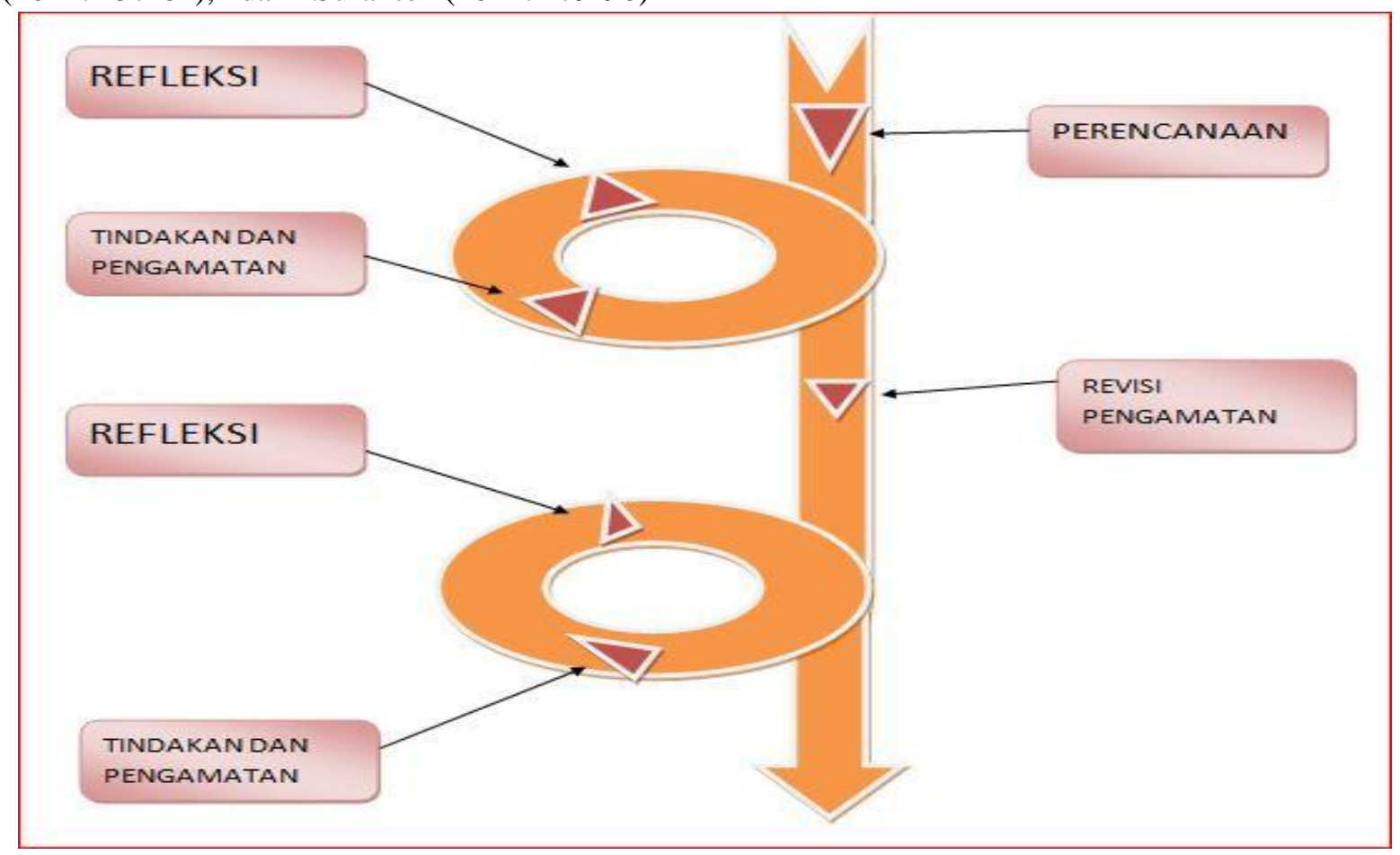

Gambar 1. Model Siklus Kemmis \& Mc Taggart (Sumber: Kemmis \& Mc Taggart, 1990: 11) 
Waktu penelitian dilaksanakan bulan Agustus 2019 sampai bulan November 2019, pada semester gasal tahun pelajaran 2019/2014. Pelaksanaan tindakan penelitian direncana-kan selama tatap muka dan proses pembelaja-ran IPS berlangsung yaitu empat jam pelajaran dalam setiap minggu yang dibagi dalam dua kali pertemuan.Tempat penelitian adalah SMPN 1 Randudongkal, Magelang yang beralamat di jalan Raya Semarang, Kecamatan Secang, Kabupaten Magelang.

Subjek dalam penelitian ini adalah peserta didik kelas VIII E SMPN 1 Randudongkal Magelang yang berjumlah 32 orang. Terdiri dari 19 perempuan dan 13 laki-laki. Pemilihan subjek didasarkan pada observasi awal dimana peserta didik kelas VIIIE memiliki keterampilan sosial dan hasil belajar rendah yaitu hanya $37,5 \%$ peserta didik yang terampil dan ketuntasan bela-jar secara klasikal hanya $40,62 \%$ dari peserta didik yang memenuhi KKM 75.

Jenis tindakan yang akan dilakukan dalam penelitian ini adalah menerapkan model pembelajaran kooperatif tipe TGT dengan variasi per-mainan. Berdasarkan model Kemmis dan Mc Taggart yang digunakan dalam penelitian tidakan kelas, maka rencana tindakan yang akan dilaku-kan untuk tiap-tiap siklus adalah sebagai berikut:

Tahap Perencanaan yaitu menyusun dan mempersiapkan semua kelengkapan proses pembelajaran dalam penelitian ini seperti: Silabus, RPP, LKS, games akademik, tes hasil belajar dan lembar pengamatan.

Tahap Pelaksanaan, Tindakan dalam peneli-tian ini akan dilaksanakan dalam 3 kali perte-muan untuk tiap siklusnya. Tindakan dilakukan berdasarkan langkah-langkah dalam komponen TGT (Slavin, 2005, pp.166-167) yaitu presentasi kelas, Kerja tim, games, turnamen dan rekognisi.

Tahap observasi, dilaksanakan selama proses pembelajaran di kelas bersamaan dengan tahap pelaksanaan dengan menggunakan lembar observasi yang telah dibuat. Observasi dilakukan untuk melihat secara langsung pelaksanaan ket-erampilan sosial peserta didik pada saat pembela-jaran terutama pada saat presentasi kelas, kerja kelompok dan permainan atau games. Observasi dilakukan juga terhadap kegiatan guru untuk mengetahui terlaksananya tahapantahapan dalam kegiatan pembelajaran.

Tahap Refleksi, dalam tahap ini peneliti, guru sebagai pelaksana tindakan dan teman sejawat mengkaji proses selama pembelajaran, masalah-masalah yang muncul dan segala hal yang berkaitan dengan tindakan yang telah dilakukan dengan berdiskusi. Refleksi ini seba-gai acuan dalam penetapan perencanaan tinda-kan pada siklus selanjutnya. Setelah suatu siklus berakhir, peneliti dan guru serta teman sejawat mendiskusikan hasil pengamatan dan hasil tes untuk tingkat keberhasilan yang dicapai peserta didik dalam pembelajaran IPS dengan penerapan model kooperatif TGT dengan variasi permainan. Siklus dihentikan apabila kriteria keberhasilan dalam penelitian ini telah tercapai.

Untuk memperoleh informasi yang berkaitan dengan keterampilan sosial dan hasil belajar maka teknik pengumpulan data dilakukan dengan observasi, wawancara, tes hasil belajar, catatan lapangan dan dokumentasi.

Observasi atau pengamatan dilaksanakan untuk mendapatkan data-data yang diperlukan dalam proses pembelajaran dengan mengamati keterampilan sosial peserta didik. Adapun dalam penelitian inihanya difokuskan pada ket-erampilan bekerja sama dan keterampilan berko-munikasi yang dilakukan oleh peserta didik. Pengamatan juga dilakukan terhadap guru untuk mengetahui keterlaksanaan pembelajaran den-gan menggunakan model koopertif TGT (Teams Games Tournaments) dengan variasi permainan.

Tehnik analisis data yang digunakan dalam penelitian ini adalah deskriptif kuantitatif yang didukung data kualitatif digunakan untuk menga-nalisis keterampilan sosial dan hasil belajar IPS. 
Data hasil pengamatan keterampilan sosial yang diperoleh dianalisis untuk memberikan gambaran realitas tentang ada tidaknya peningka-tan keterampilan sosial pada peserta didik dalam setiap siklusnya setelah penerapan model pemb-elajaran kooperatif TGT dengan variasi per-mainan pada pembelajaran IPS. Adapun dalam instrumen observasi keterampilan sosial peserta didik berisi 10 butir pernyataan. Pemberian skor pada instrumen observasi pada setiap pernyataan diberi skor 1 jika peserta didik menunjukan atau melakukan keterampilan sosial, dan skor 0, jika peserta didik tidak menunjukan atau melakukan keterampilan sosial sesuai pada butir pernyataan. Dari skor yang diperoleh peserta didik kemu-dian dikonversi menjadi nilai dan dibuat kriteria penilaian untuk keterampilan sosial peserta didik adalah sebagai berikut:

Tabel 1. Rentang Penilaian Keterampilan Sosial

\begin{tabular}{|c|c|c|c|c|}
\hline \multirow{2}{*}{\multicolumn{2}{|c|}{ Io Staor Total }} & \multicolumn{2}{|c|}{ liliaiKonreessi } & \multirow{2}{*}{ Kategoyil' } \\
\hline & & Anghla & Huruf & \\
\hline 1 & $7,6 \cdot 10$ & 76.100 & A & Sangat Terampil \\
\hline 2 & $5,1,-7,5$ & 51.75 & $B$ & Termmil \\
\hline 3 & $2,6 \cdot 5$ & 26.50 & $c$ & Cukip Terampill \\
\hline 4 & $0-2,5$ & 0.25 & D & Kurang Termpil \\
\hline
\end{tabular}

Kriteria untuk mengambil keputusan apa-kah model pembelajaran kooperatif TGT dapat meningkatkan keterampilan sosial peserta didik adalah apabila perolehan nilai rata-rata keter-ampilan sosial secara klasikal menunjukkan adanya peningkatan pada setiap siklusnya. Rata-rata nilai keterampilan secara klasikal dihitung menggunakan rumus sebagai berikut:

$$
\sum_{M=N^{x}} \underline{x 100}
$$

Keterangan:

M : Rata-rata $\sum \mathrm{x} \quad$ : Jumlah nilai yang diperoleh seluruh siswa

$\mathrm{N}$ : Banyaknya siswa yang mengikuti tes

100 : Bilangan tetap

Persentase peserta didik yang memiliki kat-egori terampil dihitung dengan rumus:

Jumlah siswa mencapai kategori $\geqq$ terampil

$\times 100 \%$ Jumlah seluruh siswa

Data hasil belajar peserta didik diperoleh dari pelaksanaaan tes ulangan yang dilaksanakan pada setiap akhir siklus untuk dianalisis. Tes yang dirancang dalam penelitian ini merupa-kan soal pilihan ganda. Data yang diperoleh dari tes dianalisis untuk melihat ketuntasan belajar peserta didik secara individu dan klasikal.

Hasil belajar tersebut kemudian dianalisis, penilaian ketuntasan belajar secara individu atau nilai tes individu dianalisis dengan rumus (Purwanto, 2009, p.207):

$$
\text { Nilai }=\frac{\text { Skor yang diperoleh siswa }}{\text { Skor Maksimal }} \times 100 \%
$$

Sedangkan untuk penilaian ketuntasan belajar klasikal menggunakan rumus sebagai berikut :

Ketuntasan Belajar Kasikal $=\underline{\text { Jumlah siswa mencapai KKM }}$ $\times 100 \%$ Jumlah seluruh siswa

Berdasarkan Kurikulum Tingkat Satuan Pendidikan (KTSP) SMPN 1 Randudongkal, seorang peserta didik dikatakan tuntas belajar secara individu bila telah memenuhi nilai KKM (75). Dalam penelitian ini diharapkan hasil bela-jar peserta didik memenuhi nilai kriteria ketun-tasan minimal $\geq 85 \%$ dari jumlah peserta didik

\section{Hasil dan pembahasan}

Sebelum Tindakan

Pada awal penelitian dilakukan observasi dengan tujuan untuk mengetahui kondisi secara umum kelas VIII dan problem dalam 
pembelaja-ran pada kelas atau subjek penelitian yaitu kelas VIII E.

Dari data observasi yang diperoleh dapat diungkapkan bahwa peserta didik masih banyak yang belum memiliki keterampilan sosial yaitu dalam bekerja sama dan berkomunikasi. Hal ini terlihat pada saat pelaksanaan diskusi berlang-sung sebagian besar peserta didik tidak aktif dan banyak dari mereka yang hanya diam dan berbic-ara dengan teman lain, sedang yang sebagian lagi sibuk mengerjakan tugas dikusi. Hal ini hampir terlihat di setiap kelompok dan ketika guru mem-inta kelompok untuk presentasi, justru kelompok saling tunjuk sehingga guru harus turun tangan dengan menunjuk kelompok yang presentasi lebih dahulu. Ketika kelompok yang lain diminta untuk menanggapi tidak satupun kelompok yang mau mengemukakan pendapatnya, hal ini mem-buat guru bingung apakah peserta didik sudah paham dengan presentasi yang disampaikan kelompok yang maju ataukah belum sehingga guru akhirnya memberikan penjelasan kembali apa yang dipresentasikan kelompok yang maju.

Berdasarkan pengamatan sebelum tindakan maka diperoleh hasil keterampilan sosial kelas VIII E sebagai berikut:

1. Rata-rata nilai keterampilan sosial peserta didik secara klasikal masih rendah yaitu 46,88 dengan persentase siswa $\geq$ terampil $37,5 \%$

2. Persebaran perolehan keterampilan sosial peserta didik dapat di lihat pada tabel berikut ini:

Tabel 2. Rekapitulasi Hasil Pengamatan Keterampilan Sosial Sebelum Tindakan

\begin{tabular}{ccccc}
\hline & & & \multicolumn{2}{c}{ Sebelum Tindakan } \\
\cline { 3 - 5 } No & Skor & Kategori & $\begin{array}{c}\text { Jumlah } \\
\text { Siswa }\end{array}$ & Persentase \\
\hline 1 & $7,6-10$ & Sangat Terampil & 3 & $9,375 \%$ \\
2 & $5,1-7,5$ & Terampil & 9 & $28,125 \%$ \\
3 & $2,6-5,0$ & Cukup Terampil & 12 & $37,5 \%$ \\
\hline 4 & $0-2,5$ & Kurang Terampil & 8 & $25 \%$ \\
\hline
\end{tabular}

Berdasarkan data hasil belajar peserta didik sebelum diberi tindakan yang diambil dari rata-rata hasil ulangan harian pada K.D sebelumnya yaitu K.D 1.3 maka dapat direkapitulasi hasil ulangan harian sebelum diberi tindakan adalah sebagai berikut:

Tabel 3. Rekapitulasi Hasil Ulangan Harian Sebelum Diberi Tindakan

\begin{tabular}{cll}
\hline No & \multicolumn{1}{c}{ Uraian } & \multicolumn{1}{c}{$\begin{array}{c}\text { Hasil Sebelum } \\
\text { Tindakan }\end{array}$} \\
\hline 1 & $\begin{array}{l}\text { Nilai rata-rata Ulangan } \\
\text { Harian }\end{array}$ & 71,62 \\
2 & $\begin{array}{l}\text { Jumlah peserta didik } \\
\text { yang tuntas belajar } \\
3\end{array}$ & 13 \\
& $\begin{array}{l}\text { Perentase ketuntasan } \\
\text { klasikal }\end{array}$ & 40,62 \\
\hline
\end{tabular}

Berdasarkan tabel di atas dapat dijelaskan bahwa sebelum diberi tindakan rata-rata hasil belajar yang diperoleh adalah 71,62 dengan ketuntasan klasikal 40,62\% yang berarti dari 32 peserta didik hanya 13 peserta didik yang tun-tas belajar dan 19 peserta didik yang lain masih belum tuntas. Berdasarkan keadaan ini, peneliti mengusulkan untuk menerapkan model pemb-elajaran kooperatif tipe TGT dengan variasi permainan.

Tindakan Siklus 1

Perencanaan dilakukan dengan mempersiapkan perangkat pembelajaran yang terdiri dari Silabus, RPP, LKS, games akademik berupa teka-teki silang, dan soal ulangan harian siklus 1. Selain itu juga dipersiapkan lembar observasi keterampilan sosial peserta didik dan lembar observasi kegiatan guru selama kegiatan belajar mengajar berlangsung.

Pelaksanaan kegiatan pembelajaran pada siklus 1 dilakukan dalam tiga kali pertemuan yaitu pada tanggal 11, 18, dan 21 Oktober 2019 di kelas VIII E dengan jumlah peserta didik 32. Pertemuan pertama dilakukan pada hari jumat, tanggal 11 Oktober 2019, jam 08.10-09.30 pembelajaran dimulai dengan guru mem-beri salam, mengabsen peserta didik dan menyam-paikan tujuan pembelajaran hari itu. Guru menje-laskan langkah-langkah pembelajaran yang akan berlangsung untuk 
hari itu dan meminta peserta didik untuk mengikuti proses pembelajaran tersebut.

Dengan metode ceramah bervariasi guru menyampaikan materi Kedatangan Bangsa Barat ke Indonesia, Kebijakan-Kebijakan Kolonial dan Pengaruhnya. Setelah itu guru membagi peserta didik secara heterogen berdasarkan hasil ulangan harian $\mathrm{KD}$ sebelumnya dan dibagi dalam 8 kelompok. Setiap kelompok diberi lembar kerja yang harus diselesaikan atau dijawab oleh kelompok dalam waktu 15 menit. Pembelajaran dilanjutkan dengan presentasi hasil kerja kelom-pok, dan ketika presentasi berlangsung tidak ada kelompok yang menanggapi atau memberikan pendapat, sehingga akhirnya guru bersama-sama peserta didik mengklarifikasi jawaban tersebut. Kelompok yang presentasi adalah Kelompok D. Selama peserta didik berdiskusi dan melakukan presentasi, guru, peneliti dan pengamat menga-mati keterampilan sosial sesuai dalam lembar observasi. Kegiatan pembelajaran berikutnya adalah melakukan permainan teka-teki silang yang harus diselesaikan oleh kelompok. Guru menjelaskan aturan permainan bahwa hasil yang diperoleh dalam permainan hari ini menjadi modal untuk skor kelompok. Ketika permainan kelompok berlangsung terlihat antusias masing-masing kelompok untuk dapat menyelesaikan permainan tesebut.

Pertemuan kedua siklus 1 dilaksana-kan pada hari jumat tanggal 18 Oktober 2019, jam 08.10-09.30. Kegiatan pembelajaran dilakukan dengan metode yang sama dengan materi Perlawanan Rakyat terhadap Kolonial Belanda dan Daerah-Daerah Penyebaran Agama Nasrani di Indonesia. Pada pertemuan ini guru memberikan presentasi materi selama 25 menit kemudian dilanjutkan dengan kerja kelompok, setiap kelompok diberi lembar kerja. Setelah semua kelompok selesai mengerjakan lembar kerja, salah satu kelompok tanpa diminta maju ke depan untuk presentasi (Kelompok E). Selama presentasi berlangsung beberapa peserta didik memberikan tanggapan dan guru memfasilitasi pelaksanaan diskusi dan hal ini berlangsung sam-pai bel berbunyi. Sambil menutup pembelajaran guru mengingatkan peserta didik untuk memper-siapkan turnamen pada pertemuan berikutnya. Selama diskusi berlangsung guru, peneliti dan pengamat mengamati keterampilan sosial peserta didik.

Pertemuan ketiga siklus 1 dilaksanakan pada hari senin, tanggal 21 Oktober 2019, jam 08.30-09.50. Pada pertemuan ini masih melanjutkan kegiatan pembelajaran pada pertemuan sebelumnya dengan mengadakan turnamen. Guru mengatur tempat duduk untuk turnamen dengan membacakan posisi masingmasing peserta didik yang intinya sesuai dengan kelom-pok prestasi (hanya guru yang tahu). Setelah peserta didik sudah benar dengan posisinya maka guru membagikan permainan teka-teki silang kepada masingmasing peserta didik untuk diker-jakan. Setelah selesai semua, guru bersama-sama peserta didik melakukan penskoran terhadap hasil turnamen tersebut. Berdasarkan skor awal kelompok dan hasil turnamen dapat diketahui bahwa pemenangnya sebagai berikut: Kelompok A sebagai Tim Baik, Kelompok E sebagai Tim Sangat Baik, dan Kelompok C sebagai Tim Super. Setelah itu guru memberikan penghargaan kepada pemenang turnamen dan menutup pembelajaran hari itu.

Hasil observasi terhadap keterampilan sosial dan hasil belajar peserta didik dapat disimpulkan bahwa telah terjadi peningkatan pada keterampi-lan sosial peserta didik. Pada Siklus 1 diperoleh rata-rata nilai keterampilan sosial peserta didik secara klasikal adalah 72,66. Hal ini berarti rata-rata nilai keterampilan sosial secara klasikal ter-masuk dalam kriteria terampil. Hasil pengamatan keterampilan sosial pada pertemuan pertama dan kedua dapat direkap pada tabel berikut: 
Tabel 4. Rekapitulasi Hasil Pengamatan Keterampilan Sosial Pertemuan Pertama dan Kedua Siklus 1

\begin{tabular}{ccccccc}
\hline \multirow{2}{*}{ No } & \multirow{2}{*}{ Skor } & Kategori & \multicolumn{2}{c}{ Pertemuan 1 } & \multicolumn{2}{c}{ Pertemuan 2 } \\
& & & Jml Siswa & \% & Jml Siswa & \% \\
\hline 1 & $7,6-10$ & Sangat Terampil & 4 & 12,5 & 16 & 50 \\
2 & $5,1-7,5$ & Terampil & 20 & 62,5 & 12 & 37,5 \\
3 & $2.6-5$ & Cukup Terampil & 8 & 25 & 4 & 12,5 \\
4 & $0-2,5$ & Kurang Terampil & - & - & - & - \\
\hline \multicolumn{2}{l}{ JUMLAH } & & 32 & 100 & 32 & 100 \\
\hline
\end{tabular}

Adapun rata- rata hasil pengamatan keterampilan sosial dari pertemuan pertama dan kedua pada siklus 1 dapat dikategorikan sebagai berikut:

Tabel 5. Kategori Rata-Rata Hasil Pengamatan Keterampilan Sosial Siklus 1

\begin{tabular}{|c|c|c|c|c|}
\hline \multirow[b]{2}{*}{ No } & \multirow[b]{2}{*}{ Skor } & \multirow[b]{2}{*}{ Kategori } & \multicolumn{2}{|c|}{ Siklus 1} \\
\hline & & & $\begin{array}{c}\text { Jml } \\
\text { Siswa }\end{array}$ & $\begin{array}{c}\text { Persen- } \\
\text { tase }\end{array}$ \\
\hline 1 & $7,6-10$ & Sangat Terampil & 15 & 46,875 \\
\hline 2 & $5,1-7,5$ & Terampil & 15 & 46,875 \\
\hline 3 & $2.6-5$ & Cukup Terampil & 2 & 6,25 \\
\hline 4 & $0-2,5$ & Kurang Terampil & - & - \\
\hline \multicolumn{2}{|c|}{ JUMLAH } & & 32 & 100 \\
\hline
\end{tabular}

Berdasarkan tabel di atas maka diperoleh penjelasan bahwa dari 32 peserta didik, yang kurang terampil nihil atau $0 \%$. Jumlah peserta didik yang cukup terampil berjumlah 2 orang dengan persentase $6,25 \%$. Peserta didik dengan kategori terampil berjumlah 15 orang dengan persentase $46,875 \%$, dan peserta didik yang sangat terampil berjumlah 15 orang dengan persentase $46,875 \%$.

Hasil belajar peserta didik pada siklus 1 diperoleh dari tes ulangan harian yang dilakukan pada akhir siklus. Berdasarkan data hasil belajar siklus 1 maka dapat direkap hasil belajar pada siklus 1 sebagai berikut :
Tabel 6. Rekapitulasi Hasil Belajar pada Siklus 1

\begin{tabular}{llc}
\hline No & \multicolumn{1}{c}{ Uraian } & Hasil \\
& Siklus 1 \\
\hline 1 & Nilai rata-rata Ulangan Harian & 77,65 \\
2 & Jumlah peserta didik yang tuntas & 25 \\
& Belajar & \\
3 & Persentase ketuntasan klasikal & 78,12 \\
\hline
\end{tabular}

Berdasarkan rekapitulasi hasil belajar pada siklus 1 tersebut di atas, maka diperoleh bahwa rata-rata hasil belajar adalah 77,65 dan ban-yaknya peserta didik yang tuntas belajar ada 25 orang yang berarti ketuntasan klasikal men-capai $78,12 \%$. Hasil ini menunjukkan adanya peningkatan yang sangat signifikan terutama dalam persentase ketuntasan klasikal dari sebe-lum tindakan $40,62 \%$ dan pada siklus 1 menjadi $78,12 \%$ sehingga terdapat peningkatan sebesar $37,5 \%$ Peningkatan hasil belajar dapat dikare-nakan adanya kerjasama dan komunikasi yang terjalin pada kelompok untuk membantu teman sekelompoknya mempelajari materi yang diberi-kan dengan harapan kelompok mereka memper-oleh penghargaan atau kemenangan.

Hasil observasi terhadap guru selama proses pembelajaran berlangsung dapat diketahui bahwa guru secara garis besar sudah mampu menerap-kan metode kooperatif TGT dengan variasi per-mainan teka-teki silang, walaupun masih ada kekurangankekurangannya dan perlu menda-patkan perhatian dalam proses pembelajaran. Kekurangan yang berhasil peneliti dan teman 
sejawat amati adalah guru terlihat masih kurang percaya diri dalam proses pembelajaran seh-ingga dalam menyampaikan materi pembelajaran tidak runtut. Guru belum melakukan bimbingan terhadap peserta didik ketika pelaksanaan kerja kelompok dan belum memberikan perhatian secara merata kepada semua kelompok. Guru juga belum dapat mengelola waktu dengan baik, sehingga sering kali kegiatan refleksi belum terlaksana.

Berdasarkan hasil pengamatan dari pelaksanaan pembelajaran siklus 1 diperoleh informasi sebagai berikut:

1. Guru kurang percaya diri dalam menyam-paikan pembelajaran.

2. Guru kurang dalam memberikan bimbingan kepada kelompok ketika kegiatan diskusi berlangsung.

3. Guru kurang memperhatikan pengelolaan waktu.

4. Ketika permainan atau turnamen berlang-sung terlihat ketegangan dari wajah peserta didik, peserta didik kurang rileks dalam per-mainan tersebut.

5. Peserta didik sebagian besar terlihat antu-sias meskipun agak tegang peserta didik merasa sangat senang dalam mengikuti pembelajaran.

6. Hasil pengamatan dari keterampilan sosial menunjukkan $93,75 \%$ peserta didik sudah terampil dan dari tes hasil belajar ketuntasan klasikal diperoleh $78,12 \%$ yang berarti belum mencapai batas ketuntasan klasikal yaitu $85 \%$.

Berdasarkan informasi tersebut maka perlu membuka siklus ke 2 karena ketetuntasan klasi-kal belum mencapai $85 \%$ dengan revisi sebagai berikut :

1. Guru perlu menumbuhkan kepercayaan diri dan bersemangat dalam menyampaikan pembelajaran, sehingga akan lebih memo-tivasi meningkatkan antusias peserta didik dalam mengikuti pembelajaran.

2. Guru harus lebih dekat dengan peserta didik, dan memberikan bimbingan ketika diskusi kelompok berlangsung.
3. Guru harus mendistribusikan waktu secara baik sehingga kegiatan pembelajaran dapat berjalan sesuai dengan harapan.

4. Perlu mencari jenis permainan yang bisa membuat peserta didik rileks dan menikmati permainan tersebut.

\section{Tindakan Siklus 2}

Tahap awal pada siklus 2 ini peneliti mem-persiapkan perangkat pembelajaran yang terdiri dari Silabus, RPP, LKS, games akademik berupa kantong jawaban atau amplop jawaban, dan soal ulangan harian siklus 2. Selain itu juga diper-siapkan lembar observasi keterampilan sosial peserta didik dan lembar observasi kegiatan guru selama kegiatan belajar mengajar berlangsung.

Pelaksanaan kegiatan pembelajaran siklus 2 dilakukan dalam tiga kali pertemuan yaitu pada tanggal 25, 26 Oktober dan 1 November 2018 di kelas yang sama yakni VIII E.

Pertemuan pertama siklus 2 dimulai dengan guru memberi salam, mengabsen peserta didik dan menyampaikan tujuan pembelajaran hari itu. Guru menjelaskan langkah-langkah pembelajaran yang akan berlangsung untuk hari itu dan meminta peserta didik untuk mengikuti proses pembelajaran tersebut. Dengan metode ceramah bervariasi guru menyampaikan materi hari itu yakni Pengaruh Perluasan Kekuasaan Kolonial, Perkembangan Pendidikan Barat, dan Perkembangan Pendidikan Islam Terhadap Munculnya Nasionalisme Indonesia dan Peranan Golongan Terpelajar, Professional, dan Pers dalam Menumbuhkembangkan Kesadaran Nasional Indonesia. Setelah itu guru membagi peserta didik secara heterogen dalam 8 kelompok seperti pada siklus 1dan peserta didik langsung menempatkan diri pada kelompoknya masing-masing. Setiap kelompok diberi lembar kerja yang harus diselesaikan atau dijawab oleh kelompok dalam waktu 15 menit. Pembelajaran dilanjutkan dengan presentasi hasil kerja kelompok, guru menawarkan kepada kelompok yang mau maju presentasi dan kelompok yang bersedia 
presentasi adalah Kelompok A. Ketika presentasi berlangsung beberapa peserta didik mengemu-kakan pendapatnya dan guru membantu meng-klarifikasi jawaban tersebut. Selama peserta didik berdiskusi dan melakukan presentasi, guru, peneliti dan pengamat mengamati keterampilan sosial sesuai dalam lembar observasi.

Kegiatan pembelajaran berikutnya adalah melakukan permainan kantong jawaban yang harus diselesaikan oleh kelompok. Guru menjelaskan aturan permainan. Ketika permainan kelompok berlangsung terlihat antusias masing-masing kelompok untuk dapat menyelesaikan permainan dengan cepat untuk mendapatkan kemenangan. Komunikasi diantara peserta didik dalam kelompok mulai terlihat dalam permainan ini. Guru kembali memberikan penjelasan bahwa skor yang diperoleh dalam permainan saat itu belum final dan kemenangan kelompok baru diketahui setelah diadakan turnamen.

Kegiatan pembelajaran kedua siklus 2 dilakukan dengan metode yang sama den-gan materi Kronologis penggunaan Istilah "Indonesia" sebagai Identitas Nasional, Perkembang Pergerakan Nasioanal, dan Peranan Manifesto Politik 1925, Kongres Pemuda 1928 dan Kongres Perempuan Pertama dalam Proses Pembentukan Identitas Kebangsaan Indonesia. Pertemuan kedua dilaksanakan tanggal 26 Oktober 2018, guru memberikan presentasi materi selama 25 menit kemudian dilanjutkan dengan kerja kelompok, setiap kelompok diberi lembar kerja. Setelah semua kelompok selesai mengerjakan lembar kerja, salah satu kelompok tanpa diminta maju ke depan untuk presentasi (Kelompok B). Selama presentasi berlangsung sebagian besar Tabel 7. Rekapitulasi Hasil Pengamatan Keterampilan Sosial Pertemuan Pertama dan Kedua Siklus 2

\begin{tabular}{ccccccc}
\hline \multirow{2}{*}{ No } & \multirow{2}{*}{ Skor } & \multirow{2}{*}{ Kategori } & \multicolumn{2}{c}{ Pertemuan 1 } & \multicolumn{2}{c}{ Pertemuan 2 } \\
\cline { 4 - 7 } & & Jml Siswa & \% & Jml Siswa & \% \\
\hline 1 & $7,6-10$ & Sangat Terampil & 12 & 37,5 & 22 & 68,75 \\
2 & $5,1-7,5$ & Terampil & 18 & 56,25 & 10 & 31,25 \\
3 & $2.6-5$ & Cukup Terampil & 2 & 6,25 & - & - \\
4 & $0-2,5$ & Kurang Terampil & - & - & - & - \\
\hline
\end{tabular}

peserta didik memberikan tangga-pan dan guru memfasilitasi pelaksanaan diskusi. Selama diskusi berlangsung guru, peneliti dan pengamat mengamati keterampilan sosial peserta didik. Kegiatan berikutnya guru bersama-sama peserta didik membuat kesimpulan dan menutup pembelajaran hari itu dengan refleksi dan doa.

Pertemuan ketiga siklus 2 dilaksanakan pada hari jumat, tanggal 1 November 2018, jam 08.10-09.30. Pertemuan ketiga ini diadakan turnamen. Guru mengatur tempat duduk untuk turnamen sesuai dengan prestasi masing-masing peserta didik. Guru meminta posisi peserta didik saling berhadapan. Turnamen dengan posisi yang saling berhadapan ini dimaksudkan agar turna-men yang dilaksanakan kali ini benar-benar memberikan suasana bahwa mereka sedang mewakili kelompoknya untuk berhadapan dengan kelom-pok lain dan berkompetisi untuk kemenangan kelompoknya. Setelah peserta didik sudah benar dengan posisinya maka guru membagikan kartu permainan kepada masing-masing peserta didik untuk dimasukkan dalam kantong-kantong yang sesuai. Setelah turnamen selesai maka guru dan peserta didik menskor dan menilai hasil per-mainan, dan memberikan penghargaan pada kelompok pemenang turnamen.

Hasil observasi atau pengamatan terhadap keterampilan sosial dan hasil belajar peserta didik pada siklus 2 menunjukkan adanya peningkatan keterampilan sosial peserta didik. Peningkatan keterampilan sosial tersebut dapat dilihat pada tabel berikut ini: 
Berdasarkan hasil pengamatan keterampilan sosial pada pertemuan pertama dan kedua maka rata-rata nilai keterampilan sosial peserta didik secara klasikal adalah 80,78. Adapun kategori rata- rata hasil pengamatan keterampilan pada siklus 2 adalah sebagai berikut:

Tabel 8. Kategori Rata-rata Hasil Pengamatan Keterampilan Sosial Siklus 2

Siklus 2

\begin{tabular}{cclcc} 
No & Skor & \multicolumn{1}{c}{ Kategori } & $\begin{array}{c}\text { Jml } \\
\text { Siswa }\end{array}$ & $\begin{array}{c}\text { Persen- } \\
\text { tase }\end{array}$ \\
\hline 1 & $7,6-10$ & Sangat Terampil & 17 & 53,125 \\
2 & $5,1-7,5$ & Terampil & 15 & 46,875 \\
3 & $2.6-5$ & Cukup Terampil & - & - \\
4 & $0-2,5$ & Kurang Terampil & - & - \\
\hline JUMLAH & & $\mathbf{3 2}$ & $\mathbf{1 0 0}$
\end{tabular}

Berdasarkan tabel di atas maka diperoleh penjelasan bahwa peserta didik yang kurang terampil dan cukup terampil tidak ada, yang berarti persentase $0 \%$, sedangkan peserta didik dengan kategori terampil berjumlah 15 orang dengan persentase $46,875 \%$, dan peserta didik dengan kategori sangat terampil berjumlah 17 orang den-gan persentase 53,125\%.

Hasil belajar peserta didik pada siklus 2 dapat dilihat dari rekapitulasi hasil belajar berikut ini:

Tabel 9. Rekapitulasi Hasil Belajar Siklus 2

\begin{tabular}{llc}
\hline No & \multicolumn{1}{c}{ Uraian } & Hasil Siklus 2 \\
\hline 1 & $\begin{array}{l}\text { Nilai rata-rata Ulangan } \\
\text { Harian }\end{array}$ & 85,16 \\
2 & $\begin{array}{l}\text { Jumlah peserta didik yang } \\
\text { tuntas belajar }\end{array}$ & 28 \\
3 & $\begin{array}{l}\text { Persentase } \\
\text { klasikal }\end{array}$ \\
\hline
\end{tabular}

Berdasarkan data tersebut di atas maka diperoleh rata-rata hasil belajar peserta didik ada-lah 85,16 dan dari 32 peserta didik yang telah tuntas sebanyak 28 dan yang belum tuntas ada 4, hal ini berarti secara klasikal ketuntasannya telah mencapai $87,5 \%$. Peningkatan pada siklus 2 ini dipengaruhi oleh adanya peningkatan kemam-puan guru dan kepercayaan diri guru dalam men-erapkan pembelajaran model kooperatif TGT, sehingga peserta didik mudah memahami materi yang diberikan dan dengan permainan yang berganti dengan amplop jawaban menjadikan peserta didik lebih rileks, tertarik dan tertantang dengan model pembelajaran tersebut.

Hasil observasi terhadap guru selama proses pembelajaran berlangsung dapat diketahui bahwa guru sudah mampu menerapkan model kooperatif TGT dengan variasi permainan kantong jawaban. Guru sudah melaksanakan semua langkah-lang-kah dalam pembelajaran model kooperatif TGT. Guru sudah mulai memiliki kepercayaan diri dalam pembelajaran sehingga kegiatan belajar mengajar berjalan lancar dan cukup baik

Hasil refleksi terhadap pelaksanaan tindakan siklus 2 dapat dirinci sebagai berikut:

1. Guru mampu mengelola kelas, sehingga pembelajaran dapat berjalan lancar.

2. Guru sudah memiliki wawasan dalam peng-gunaan model kooperatif TGT dengan variasi permainan sehingga pembelajaran menjadi lebih menarik.

3. Guru mampu memberikan motivasi kepada peserta didik sehingga peserta didik men-guasai materi-materi yang diajarkan.

4. Peserta didik memiliki keterampilan sosial yaitu bekerja sama dan berkomunikasi dalam proses pembelajaran.

5. Peserta didik dapat bermain sportif dalam game akademik

6. Hasil pengamatan dari keterampilan sosial menunjukkan $100 \%$ peserta didik sudah ter-ampil dan dari tes hasil belajar meningkat dengan ketuntasan klasikal diperoleh $87,5 \%$ yang berarti sudah mencapai kriteria ketun-tasan klasikal yang diharapkan yaitu $85 \%$. 
Berdasarkan hasil refleksi dari siklus 2 tersebut dapat terlihat peningkatan yang cukup berarti. Hasil pengamatan keterampilan sosial yang sudah mencapai $100 \%$ dan hasil belajar peserta didik sudah mencapai $87,5 \%$ menunjuk-kan bahwa kriteria keberhasilan penelitian sudah terpenuhi, sehingga penelitian ini diakhiri pada siklus kedua.

Peningkatan keterampilan sosial dan hasil belajar tentu tidak lepas dari diterapkannya model pembelajaran kooperatif tipe TGT dengan variasi permainan. Penerapan model kooperatif TGT dengan variasi permainan mampu membuat peserta didik merasa tertarik

Tabel 10. Perbandingan Hasil Pengamatan Keterampilan Sosial Sebelum Tindakan, Siklus 1 dan Siklus 2

\begin{tabular}{cclccc}
\hline No & Skor & Kategori & Sebelum Tindakan & Siklus 1 & Siklus 2 \\
\cline { 3 - 5 } & & & Persentase & Persentase & Persentase \\
\hline 1 & $7,6-10$ & Sangat Terampil & 9,375 & 46,875 & 53,12 \\
2 & $5,1-7,5$ & Terampil & 28,125 & 46,875 & 46,875 \\
3 & $2,6-5$ & Cukup Terampil & 37,5 & 6,25 & - \\
4 & $0-2,5$ & Kurang Terampil & 25 & - & - \\
\hline
\end{tabular}

Di bawah ini ditayangkan tabel dan grafik perbandingan nilai keterampilan peserta didik sebelum tindakan, siklus 1 dan siklus 2 sebagai berikut:

Tabel 11. Perbandingan Nilai Keterampilan Sosial Sebelum Tindakan, Siklus 1 dan Siklus 2

\begin{tabular}{clccc}
\hline No & Uraian & Sebelum Tindakan & Siklus 1 & Siklus 2 \\
\hline 1 & Rata- rata Nilai Keterampilan Sosial & 46,88 & 72,66 & 80,78 \\
2 & Jumlah siswa kategori $\geq$ Terampil & 12 & 30 & 32 \\
3 & Persentase siswa kategori $\geq$ Terampil & $37,5 \%$ & $93,75 \%$ & $100 \%$ \\
\hline
\end{tabular}

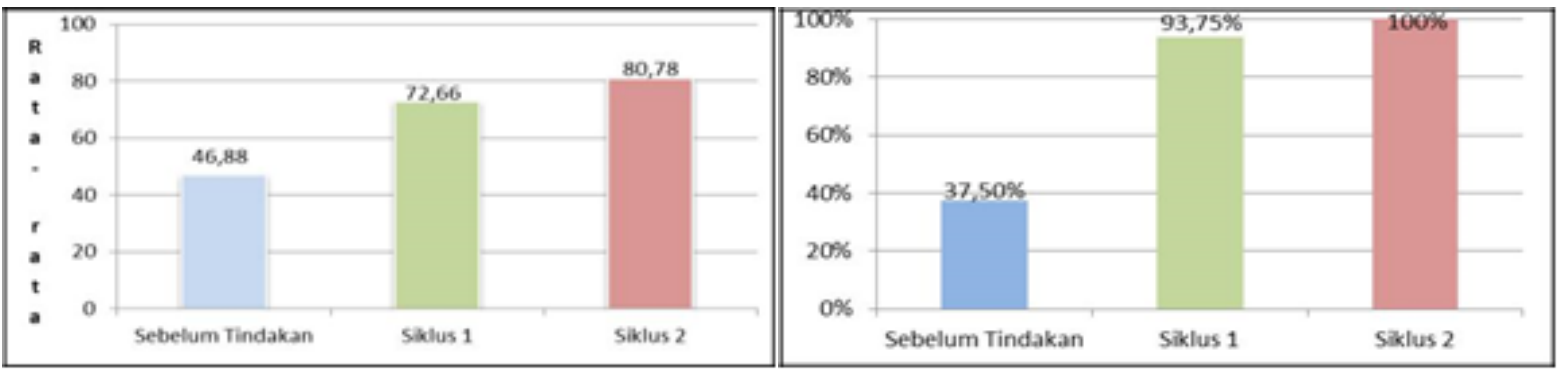

Gambar 2. Perbandingan Rata-Rata Nilai Keterampilan Sosial (kiri) \& Siswa dengan Kategori $\geq$ Terampil (kanan)

Penelitian ini menunjukkan bahwa pembelajaran model kooperatif TGT dengan variasi permainan mempunyai dampak positif terhadap peningkatan hasil belajar peserta didik. Hal ini dapat dilihat dari semakin mantapnya pemahaman materi yang diperoleh 
peserta didik yang dibuktikan dari perolehan hasil belajar pada siklus 1 dan siklus 2 bila dibandingkan dengan hasil belajar sebelum diberi tindakan yang menunjukkan adanya peningkatan, baik pada rata-rata nilai maupun pada ketuntasan klasikalnya. Perbandingan hasil belajar IPS peserta didik sebelum diberi tindakan, tindakan siklus 1 dan tindakan siklus 2 dapat dilihat pada tabel dan grafik berikut ini:

Tabel 12. Perbandingan Hasil belajar

\begin{tabular}{cllll}
\hline \multirow{2}{*}{ No } & \multicolumn{1}{c}{ Uraian } & \multicolumn{1}{c}{$\begin{array}{c}\text { Sebelum } \\
\text { Tindakan }\end{array}$} & \multicolumn{1}{c}{ Siklus 1 } & \multicolumn{1}{c}{ Siklus 2 } \\
\hline 1 & Rata-rata hasil belajar & 71,62 & 77,65 & 85,16 \\
2 & Jumlah peserta didik yang sudah tuntas & 13 & 25 & 28 \\
3 & Persentase ketuntasan klasikal & 40,62 & 78,12 & 87,5 \\
\hline
\end{tabular}

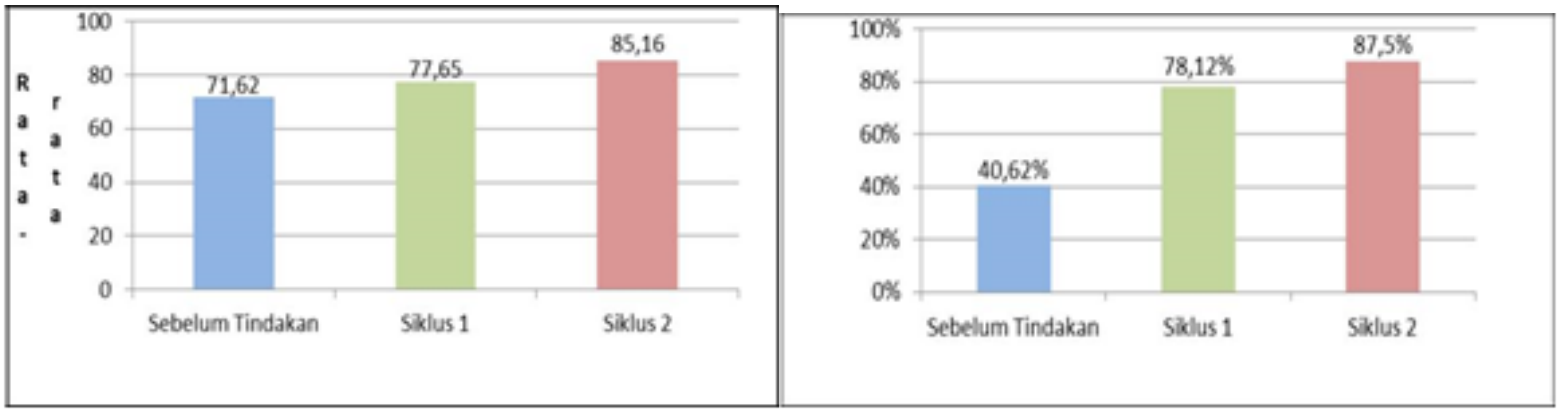

Gambar 3.

Perbandingan Rata-Rata Hasil Belajar (kiri) dan Presentasi Ketuntasan Klasikal (kanan)

\section{Simpulan}

Berdasarkan hasil penelitian, mulai dari sebelum tindakan, siklus 1 dan siklus 2, dan ber-dasarkan pembahasan peneliti, maka dapat disimpulkan bahwa Model pembelajaran kooperatif TGT den-gan variasi permainan dapat meningkatkan keterampilan sosial peserta didik kelas VIII E N 1 Randudongkal. Penerapan permainan teka-teki silang pada siklus 1 memberikan kesempatan kepada peserta didik untuk melakukan dan mengembangkan keterampilan sosialnya. Selanjutnya penerapan permainan amplop jawaban pada siklus 2 memberikan peluang semakin tinggi kepada peserta didik dalam meningkatkan kerja sama dan komuni-kasi. Peningkatan ketrampilan sosial ditunjukkan dari rata-rata nilai keterampilan sosial pada pengamatan sebelum tindakan hanya 46,88 (kategori cukup terampil), pada siklus 1 meningkat menjadi 72,66 (kategori terampil), dan meningkat lagi menjadi 80,78 (kategori

sangat terampil) pada siklus 2. Persentase peserta didik yang mencapai kategori $\geq$ terampil sebelum tindakan $37,5 \%$, pada siklus 1 meningkat menjadi $93,75 \%$ dan pada siklus 2 menjadi $100 \%$.

Model kooperatif TGT dengan variasi per-mainan dapat meningkatkan hasil belajar IPS peserta didik kelas VIII E SMPN 1 Randudongkal. Peningkatan hasil belajar ditunjukkan dari hasil rata-rata ulangan harian sebelum tindakan sebe-sar 71,62, pada siklus 1 meningkat menjadi 77,65. Siklus 2 nilai ratarata meningkat lagi menjadi 85,16. Peningkatan hasil belajar juga dapat dilihat dari persentase ketuntasan klasi-kal. Ketuntasan klasikal sebelum tindakan hanya mencapai $40,62 \%$, pada siklus 1 meningkat menjadi $78,12 \%$. Pada siklus 2 ketuntasan klasikal meningkat lagi menjadi $87,5 \%$.

\section{Referensi}


Jarolimek, J. (1986). Social studies in elementary education. New York: Mac Millan Publishing Company.

Kemmis, S. \& Taggart, R. (1990). The Action research planner. (Third Edition). Victoria: Deakin University

Muijs, D. \& Reynold, D. (2006). Effective teach-ing: Evidence and practice (2th ed). London: Sage Publication

Ngurah, A.A.G. (2005). Implementasi Model Pembelajaran Kooperatif Tipe TGT dengan Pendekatan Pembelajaran Kontekstual dan Model Evaluasinya dalam Pembelajaran Fisika di SMP Tahun Ajaran 2004/2005. Jurnal Ilmiah Pendidikan dan Pembelajaran Volume 2 Nomor 1, hal 148-162.

Rahayu, P. (2011).Peningkatan pemahaman menghitung keliling dan luas segi empat melalui pembelajaran kooperatif TGT pada siswa kelas VII SMP N 2 Klaten tahun 2010/2011. Jurnal Pendidikan Dasar, Metodika volume 1, nomor 3.hal 57-64

Purwanto. (2011). Evaluasi hasil belajar.Yogyakarta: Pustaka Pelajar.

Slavin. (2005). Cooperative learning, teori,riset dan praktik. (Terjemahan Narulita Yusron). London: Allyn and Bacon.(Buku asli diter-bitkan tahun 1995)

Slavin, R.E.(1995). Cooperative learning, theory, reseach and practice. London: Allyn and Bacon.

Slavin. (1991). Education psychology: theory into practice. Boston: Allyn and Bacon.

Suranto. (2011). Peningkatan penguasaan materi bangun datar berbahasa inggris dengan model pembelajaran team games tourna-ment (TGT) dan media kartu permainan matematika siswa kelas 7F SMP Negeri 2 Kendal semester II tahun pelajaran 2010/2011. Jurnal Pendidikan Dasar, Metodika volume 1, nomor 3.hal 79-90

Suwandi, S. (2009). Model assesmen dalam pembelajaran. Surakarta: Panitia Sertifikasi Guru (PSG) Rayon 13 Surakarta.

Widarwati, S. (2007). Implementasi model pemb-elajaran team games tournaments berba-sis tehnologi informasi pada perkuliahan kajian mode. Majalah Ilmiah Pendidikan, 2 vol 3, 224-239
Zamroni. (2007). Pendidikan dan demokrasi dalam transisi (prakondisi menuju era globalisasi). Jakarta: PSAP Muhammadiyah. 